\title{
Walk-in fotografija - \\ Od umjetnosti u kontekstu do konteksta u umjetnosti
}

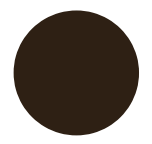

Germano Celant, Chiara Costa, ur. Post Zang Tumb Tuuum. Art, Life, Politics: Italia 1918-1943, katalog izložbe. Milano: Fondazione Prada, 2018. ISBN 9788887029710

DOI: 10.31664/zu.2018.103.08

Gotovo da i ne treba posebno naglasiti kako se u suvremenom svijetu umjetnosti, govorimo li općenito i stoga ne odviše strogo, pitanje konteksta ili kontekstualizacije čini izrazito važnim -i to s pravom. Možemo to jednostavno posvjedočiti pomoću brojnih slučajeva u kojima se i kontekst i kontekstualizacija primjenjuju u smislu kritike ili ogleda, obično negativno, i to ne nužno izložbe. Slijedom toga, pretpostavlja se da je nedostatak konteksta, koji se obično prikazuje u obliku prateće arhivske ili dokumentarne građe, a ponekad jednostavno kao pojašnjavajući tekst, nešto što treba izbjegavati. Ostanemo li na ovoj uobičajenoj razini razmišljanja, čini se da uglavnom možemo, barem simplificirajući, svesti taj zahtjev za kontekstom ili kontekstualizacijom na zahtjev za više povijesti, podataka, empiričnosti, složenosti i/ili nijansiranosti te specifičnosti i konkretnosti življenog iskustva, za razliku od suprotnog pristupa, koji možemo standardno opisati ili okarakterizirati kao puko predmetan ili, oštrijim riječima, „distanciran”, „,neutraliziran”, „fetišistički”, „formalistički” ili čak „sterilan”-sterilan poput zapadnjačke bijele kocke, poslužimo li se rječnikom koji je, kako se čini, strastveno povezan s misijom razotkrivanja društveno-povijesnih okolnosti ili jednostavno ideologije i politike u (naizgled) neutralnome ili u njegovoj pozadini.

$\rightarrow$

\section{Marko Jenko}




\section{Walk-In Photograph - From Art in Context to Context in Art}

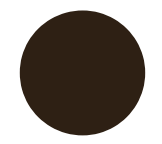

Germano Celant, Chiara Costa, ed. Post Zang Tumb Tuuum. Art, Life, Politics: Italia I9I8-I943, exhibition catalogue. Milano: Fondazione Prada, 20I8. ISBN 97888870297IO

DOI: $10.31664 / z u .2018 .103 .08$

It almost goes without saying that in the contemporary art world, if we speak generally and therefore loosely, the question of context or contextualization seems to be of utmost importance - and deservedly so. One can attest to this by simply recalling the numerous times that both context and contextualization are applied as a usually negative critique or review, not only of an exhibition. Consequently, one presumes that lacking context, which is usually presented in the form of accompanying archival or documentary materials, or sometimes simply as an explanatory text, is to be avoided. If we stay on this commonplace level of reasoning, it seems that we can, more than not, at least in simpler terms, reduce this call for context or contextualization to a call for (more) history, data, empiricalness, complexity and/or nuance, specificity and concreteness of a lived experience, as opposed to the opposite approach, which we could describe or characterize in standard terms as merely object-based or, more harshly, "detached," "neutralized," "fetishistic," "formalist," even "whitewashed," as whitewashed as the Western white cube, if we thus take recourse to a vocabulary that seems passionately bound to the mission of disclosing socio-historical circumstances or simply ideology and politics in or behind the (seemingly) neutral.
Katalog izložbe/Exhibition Catalogue Post Zang Tumb Tuuum. Art, Life, Politics: Italia I9I8-I943, Foto/Photo: Dejan Habicht 
Ovaj naglasak na čitanju, tumačenju ili čak dešifriranju vizualne šutnje, koja tjera neutralnost da progovori ili prizna nešto što se takoreći prikrivalo, ovaj naglasak na specifičnom i povijesnom ili jednostavno na objašnjavajućem i/ili tekstualnom, već je po sebi dio i posljedica poznatog i etabliranog postupka raskrinkavanja, demistifikacije ili odbacivanja iluzija, što predstavlja tipično nasljeđe danas sve ozloglašenijeg prosvjetiteljstva i kritičke teorije 20. stoljeća. No je li to sve? Ne pretvaramo li se u toj borbi protiv sterilizirajućeg neprijatelja i sami u neprijatelja, jednostavno izmještajući fetiš? I nije li navedeno nasljeđe dvosjekli mač? I ne mistificira li demistifikacija i sama na svoj način, dok reproduktibilnost ili mnogostrukost ne samo da ne umanjuje niti uništava časnu auru nego je ustvari proizvodi i učvršćuje, kao što je Walter Benjamin jasno pokazao? Nisu li mnogostrukost i aura dva lica iste medalje? Neće li defetišizirajuće razotkrivanje procesa u pozadini nekog artefakta ili predmeta ustvari čak produbiti njegovu zagonetnost ili fetišizirati zakulisnost, uključujući kontekst ili kontekstualizaciju? Nadalje, ne potiskuje li inzistiranje na čitanju i tekstualizaciji vizualnog onaj ključni i za publiku teški obrat u modernoj umjetnosti, naime korak kojim se udaljavamo od mogućnosti čitanja i dešifriranja (ili beskonačnog dešifriranja)? Znači li kontekstualizacija jednostavno da tretiramo sliku kao tekstualnu zagonetku, neku vrstu rebusa koji nas poziva da ga dešifriramo kako bismo ga oslobodili njegove nametnute neutralnosti? ${ }^{1}$ Čini se da poticaj na interpretaciju dolazi od strane predmeta-sfinge ili izvanjske materijalnosti. No predmet nije samo pitanje koje se postavlja pred nas: on je već odgovor.

Ove opaske ili pitanja dovode nas bliže biti stvari kao što ju je prikazao Germano Celant u svojem uvodnom, gotovo programatskom tekstu „Prema stvarnoj i kontekstualnoj povijesti" u katalogu izložbe o umjetnosti u vrijeme fašizma Zaklade Prada u Milanu: Post Zang Tumb Tuuum. Art, Life, Politics: Italia 1918-1943 (18. veljače-25. lipnja 2018.). Bez mnogo oklijevanja možemo ga kategorizirati kao tekst u kojem se razotkriva glavna problematika, ako ne i pristup, metoda ili jednostavno koncept te izložbe i kataloga. Oboje su Celantov osobni odgovor na probleme koje je izložio u svojem tekstu. Putanja Celantova lucidno, no zgusnuto pisanog uvodnika, s odmah jasnim značenjem stvarnog (vrlo ključne riječi) i kontekstualnog, lijepo, iako nesvjesno pokazuje (libidinalnu) ekonomiju zahtjeva za (više) konteksta. Celant započinje kratkim pregledom već poznate i mnogo proučavane povijesti pojma „prostor” i/ili načina izlaganja umjetničkih djela na Zapadu, vraćajući se u vrijeme prije pojave bijele kocke ili eskalacije onoga što je donijela secesija u pogledu umjetničkih izložbenih prostora, naime redukcije svega što nije vizualno povezano s izloženim artefaktima. Na početku, međutim, odmah osjećamo da će Celantov pristup također biti usredotočen na (auto)refleksivnost. Naime, već na samom početku teksta to izvan svake sumnje naznačuje naslov prvog odjeljka, „Prikazivanje prikazivanja”. Ovaj jednostavni moment refleksivnosti ima dvojaku funkciju: najavljuje Celantov povijesni pregled izlagačkih praksi, kada nekoliko stranica kasnije piše „Izložba umjetnosti naspram umjetnosti izlaganja”, ali i njegov implicitni, iako nikada sasvim artikulirani koncept konteksta. Taj moment refleksivnosti mogao bi se ilustrirati tako da se obrnuto shvati ona kineska poslovica: „Dok mudrac pokazuje na Mjesec, budala gleda njegov prst.” Prikazivanje prikazivanja jest prikazivanje prsta, pokazivanje na pokazujući prst. Budala je bila u pravu. Drugim riječima, on ne pokazuje na sliku, nego na ono što (nevidljivo) uokviruje sliku-uključujući kontekstualnog gospodara.

Ovaj refleksivni obrat također neizbježno otvara pitanje mogućnosti pozicije koja bi uspjela transparentno promišljati samu sebe ili najprije jednostavno mogućnosti izložbe koja bi promišljala sebe samu i to nam pokazala. Opasnost bi ovdje, dakako, bila u nekoj vrsti postmoderne prazne ironije kao svjesnog i neprekidnog samodistanciranja. Međutim, Celant se s tom mogućnošću metapozicije sasvim ozbiljno hvata u koštac. Nažalost, bilo što „meta” u strogom smislu nemoguće je već s jezične točke gledišta. Pomalo sirovim rječnikom: jednostavno se ne može stajati iza vlastitih leđa. Ta se zadaća pokazuje teškom. Čitatelj to može osjetiti
Više o problemu dešifriranja u: Wajcman, Collection. 
This emphasis on reading, interpreting or even deciphering the visual silence, making neutrality talk or confess to the unacknowledged, so to speak, this emphasis on the particular and historical, or simply the explanatory and/or the textual, is already a part and consequence of the well-known and established procedure of unveiling, demystifying or discarding illusions, very much the legacy of the now unfortunately more and more maligned Enlightenment and the 2oth century critical theory. However, is this all? Does one perhaps in fighting the whitewashing enemy turn into the enemy by simply displacing the fetish? And is it not that the abovementioned legacy cuts both ways? That demystifying can actually mystify in its own way, that reproductivity or the multiple, for instance, do not simply diminish or destroy the venerable aura, but actually produce or reinforce it, as Walter Benjamin clearly implied? That the multiple and aura are two sides of the same coin? Or that the defetishizing disclosure of the process behind an artefact or object can actually even deepen its enigma or fetishize the behind-the-scenes, including the context or contextualization? Furthermore, does the insistence on reading and textualizing the visual not repress the crucial and for the audience difficult turn in modern art, namely, the step away from the possibility to read and decipher (or endlessly decipher)? Does contextualizing simply mean that one treats a painting as a textual riddle, a rebus of sorts, calling for us to decipher it, to free it from its imposed neutrality? ${ }^{1}$ It is as if the push for an interpretation comes from the side of the object-sphynx or external materiality. But the object is not only a question put before us, it is already an answer.

These remarks or questions bring us closer to the gist of the matter as presented by Germano Celant in his opening, almost programmatic text "Toward a Real and Contextual History" in the catalogue of Fondazione Prada's Milan exhibition of art during Fascism, Post Zang Tumb Tuuum. Art, Life, Politics: Italia I9I8-I943 (February I8-June 25, 20I8). Without much hesitation, one can easily categorize it as the laying-bare of the main problematic, if not approach, method or simply concept of both the exhibition and catalogue. They are both Celant's own answers to the problems laid out by himself in his text. The trajectory of Celant's lucidly, yet densely written opening text, with an immediately clear significance of the real (very much a key word) and the contextual, nicely, yet unwittingly displays the (libidinal) economy of the call for (more) context. Celant begins with a short overview of the already known and much studied history of the term "space" and/ or modes of exhibiting artworks in the West, going back to the times before the advent of the white cube or the escalation of what the Secession brought in terms of art exhibition spaces, namely, the reduction of everything visually disconnected from the exhibited artefacts. At the outset, though, we immediately sense that Celant's approach will also be focused on (self-) reflexivity. The very beginning of the text, namely, the title of its first section, “The Showing of the Showing," signals this beyond any shadow of a doubt. This simple point of reflexivity is twofold: it both signals his historical survey of exhibition practices, i. e., as he writes a few pages later "The Exhibition of Art vs the Art of Exhibition," and his implied, but never fully articulated concept of context. One could illustrate this point of reflexivity by going against the Chinese proverb "when the sage points at the Moon, the fool looks at the finger." The showing of the showing is the showing of the finger, the pointing at the pointing finger. The fool was right. In other words, he does not point at the picture, but at what (invisibly) frames the picture-his contextual master included.

This reflexive turn also, and inevitably, opens up the question of the possibility of a position that could succeed to self-transparently think itself, or first simply the possibility of an exhibition that would think itself and show that to us. The danger here, of course, would be some sort of postmodern empty irony as the conscious and constant self-distancing. However, Celant grapples with the possibility of a meta-position with utmost seriousness. Unfortunately, anything "meta" is already from a linguistic point of view strictly impossible. To put it somewhat coarsely:
More on the problem of deciphering: Wajcman, Collection. 
u načinu na koji Celant otvoreno sam sebe dovodi u pitanje, osobito kada razmatra mogućnost hvatanja u koštac s cjelokupnošću stvari: „Je li moguće proizvesti aktivnu sintezu koja će na izložbi uzeti u obzir ne samo nekoherentnu raspodjelu umjetničkih djela... nego nastojati izgraditi cjelokupnost povijesne i društvene, poetske i estetske građe, sastavljene od dokumenata stvarnosti koji služe za kovanje ,kulturnog razumijevanja' složenosti konstelacija jedne ere?" ${ }^{2}$ To je očito ključno pitanje u pozadini kataloga i same izložbe. U tom svjetlu nemogućnost metapozicije značila bi da je obuhvaćanje i/ili prikazivanje cjelokupnosti svega nemoguće, ne samo iz čisto empirijskih razloga, odnosno zato što jednostavno postoji previše „stvari” (i stoga njegov opetovani naglasak na složenosti), nego i zbog strukturalne nemogućnosti, koja je jezične naravi. Empirijska složenost ili bezgraničnost, složenost konstelacija jedne ere, kako on to formulira, ne bi stoga bila ništa drugo do izraz strukturalnog ograničenja-također same ere i za nju. Kontekst, dakle, nije neki cjelokupni ili zatvoreni obzor, nego je nedosljedan, čak i zamršen.

Usredotočimo li se sada na implikacije cjelokupnosti i sinteze, možemo proširiti pitanje Celantova naglaska na složenosti kao empirijskoj bezgraničnosti (sve „konstelacije jedne ere”). Ne bi bilo nategnuto povezati ovu složenost, osobito uzmemo li u obzir razdoblje fašizma, sa složenošću ili jednostavno kaotičnošću (svakodnevnog) života-još jedna ključna riječ koja je prisutna već u naslovu izložbe i kataloga, a usko je povezana s umjetnicima i njihovim odlukama pod tim konkretnim režimom. ${ }^{3}$ Kako su oni plovili kroz taj život? Ovdje se možemo samo složiti s naglaskom na složenosti, koja je vrlo očigledna, kao i sa stavom da bi složenost trebala uključivati nijansirani pristup povijesti i utemeljenu točku gledišta. Inače ćemo vrlo brzo riskirati da upadnemo u zamku moralizma lijepe duše onih koji su rođeni kasnije te sude s kronološki sigurne udaljenosti. Međutim, čak i ako ta složenost stvarne ili stvarno življene povijesti, pogotovo u smislu kaotičnosti života, svakako zvuči istinito, ne bismo smjeli zaboraviti da neke stvari jesu crno-bijele i ne bi ih se smjelo zastrti nebrojenim nijansama: fašizam je jednostavno pogrešan i da, čak i tada je bilo moguće donijeti pravu odluku. ${ }^{4}$ I opet, što je to „kulturno razumijevanje složenosti konstelacija jedne ere”? Što je to što možda još uvijek ne znamo ili ne razumijemo? Kako je umjetniku bilo živjeti i stvarati pod fašizmom, kao što su Miuccia Prada i Patrizio Bertelli naznačili u svojem uvodniku? Budimo otvoreni: možemo li razumjeti fašističkog umjetnika? Što se tu ima razumjeti? Problem je u tome što „razumijevanje” i „složenost” obično podrazumijevaju neku još neotkrivenu, čak psihološku dubinu. Ne događa li se da nas prebrzo ponese složenost, minucioznost i bogatstvo pojedinosti i nijansi, ostavljajući nas bez cjelovite i jasne slike kognitivne karte-čak i kada je riječ o fašizmu? Zato Celant želi aktivnu sintezu, u osnovi sintezu velikog i malog. Jesu li stvari uopće tako složene? Ipak, osjeća se da, nažalost, neartikulirano pitanje u pozadini svih tih krivudanja o tome kako je to bilo tada ustvari ukazuje na pitanje gdje smo danas u usporedbi s onim vremenima. U tom smislu također je moguće danas donijeti pravu odluku, u aktualnoj turbulentnoj politici Italije, kao što je Barbara Casavecchia jasno napomenula. ${ }^{5}$

No što ako je pitanje koje ovdje nedostaje, pitanje koje ne spominje nijedan kritičar, koliko je poznato autoru ovog teksta, sljedeće: Je li fašizam, a time i kontekst općenito, krajnji obzor „razumijevanja” ili tumačenja umjetničkog djela, koliko god propagandističko ili režimsko bilo? I ako jest, treba li uopće govoriti o umjetnosti ili u najboljem slučaju samo o maloj umjetnosti a da ne upadnemo u zamku autonomije ili krajnje čistoće umjetnosti? ${ }^{6}$ Čini se da je problem ili jaz koji podrazumijeva ovo nedostajuće pitanje jaz između uživanja ili tumačenja umjetničkog djela (režimskog ili propagandističkog) i svijesti o strahotama koje su se dogodile pod određenim režimom. No ima li taj jaz baš tako oštre granice? Drugim riječima, je li taj akademski ili umjetničko-povjesničarski manevar o kojemu svjedoči katalog dovoljan da posluži kao neka vrsta štita objektivnosti, ako je to možda bila njegova svrha (ili znak straha od mogućih suvremenih političkih posljedica)? Što ako
2

Celant, Costa, Post Zang Tumb Tuuum.

Art, Life, Politics: Italia 1918-1943, 38.

3

Isto, 42-43.

Tu bi se moglo lako dokazati kako je fašizam prisvajao ili jednostavno iskorištavao i zloupotrebljavao ono što je uspostavila ljevica i kako je fašizam simptom neuspjeha ljevice.

Casavecchia, „Post Zang Tumb Tuuum. Art Life Politics: Italia 1918-1943 at Fondazione Prada, Milan".

Taj je problem „provokativno” razradio Slavoj Žižek u svojem tekstu „Learning to Love Leni Riefenstahl”. 
one simply cannot stand behind one's own back. The task proves difficult. The reader can sense this in the way Celant openly questions himself, especially when considering the possibility of grasping the totality of things: "Is it possible to produce an active synthesis that, in the exhibition, takes into consideration not only the incoherent distribution of the artworks ... but aims to construct a totality of historical and social, poetic and aesthetic material, made up of documents of reality that serve to forge a 'cultural understanding' of the complexity of the constellations of an era?" 2 This is evidently the question behind the catalogue and the exhibition. In this light, the impossibility of a meta-position would mean that grasping and/or displaying the totality of it all is impossible not because of mere empirical reasons, i. e., of there simply being too much "stuff" (hence his repetitive emphasis on complexity), but due to a structural impossibility, which is linguistic in nature. The empirical complexity or boundlessness, the complexity of the constellations of an era, as he puts it, would thus be nothing but the expression of a structural limit-also for and of the era itself. Context is thus not a total or closed horizon, it is inconsistent, convoluted even.

If we now focus on the implications in totality and synthesis, we can expand the question of Celant's emphasis on complexity as empirical boundlessness (all the "constellations of an era"). It would not be a stretch to link this complexity, especially when taking into account the period of Fascism, to the complexity or simply messiness of (everyday) life - another key word already present in the title of both the exhibition and catalogue, and closely linked to artists and their decisions under that particular regime. ${ }^{3}$ How did they navigate it all? Here, one cannot but agree with this emphasis on complexity, very much self-evident, and that complexity should entail a nuanced approach to history, a grounded point of view. Otherwise, we also quickly risk the trap of the beautiful-soul moralism of those born later, judging from a chronologically safe distance. However, even if this complexity of a real or really lived history, especially in terms of the messiness of life, cannot but ring true, we should not forget that some things are black-andwhite and should not be veiled by a myriad of nuances: Fascism is simply wrong and, yes, it was possible to make the right decision even then. ${ }^{4}$ Again, what is the "cultural understanding of the complexity of the constellations of an era?" What is that that we perhaps still do not know or understand? How it was for an artist to live and create under Fascism as Miuccia Prada and Patrizio Bertelli imply in their foreword? Let us be blunt: Can we understand a fascist artist? What is there to understand? The problem is that "understanding" and "complexity" tend to imply a certain yet undisclosed, even psychological depth. Is it not that we can get too quickly swept away by the complexities, the minutia, and the richness of details and nuances, left with no big, clear-cut picture of a cognitive map-of Fascism even? This is why Celant wants an active synthesis, basically of the big and the small. Are things really that complex anyway? Still, one feels that the unfortunately non-articulated question behind these meanderings of how it was then actually points to the question of where we are today compared to those times. In this respect, it is also possible to make the right decision in present times, in Italy's current turbulent politics, as Barbara Casavecchia clearly implied. ${ }^{5}$

What if the missing question here, a question not mentioned by one critic as far as the author of this text knows, is the following: Is Fascism, and therefore context in general, the ultimate horizon of "understanding" or interpreting an artwork, as propagandist or regime as it may be? If it is, should we speak of art at all or only of minor art at best, without falling into the trap of autonomy or art's ultimate cleanliness ${ }^{6}$ The problem or split, implied by this missing question, seems to be the split between enjoying or interpreting a (regime or propagandist) artwork and the awareness of the horrors under a certain regime. However, is this split really that clear-cut? In other words, is the academic or art-historical tour de force, attested by the catalogue, enough to be some sort of cold-distance shield of objectivity, if that was perhaps its intended function (or a sign of fearing possible contemporary
2

Celant, Costa, Post Zang Tumb Tuuum. Art, Life, Politics: Italia I9I8-1943, 38.

3 Ibid., $4^{2-43 .}$ 4 Here, one could easily prove how Fascism appropriated or simply misused and abused what was established by the Left, and how Fascism is the symptom of the Left's failure.

5

Casavecchia, "Post Zang Tumb Tuuum. Art Life Politics: Italia I9I8-I943 at Fondazione Prada, Milan."

6

This problem was "provocatively" developed by Slavoj Žižek in his text "Learning to Love Leni Riefenstahl." 
naša učena saznanja o strahotama u određenom sustavu funkcioniraju kao alibi, ustvari nam pomažući da uživamo u njegovim „umjetničkim djelima” bez ikakve loše savjesti, budući da i previše dobro znamo kako su stvari stajale? ${ }^{7} \mathrm{U}$ tom svjetlu, ipak, bilo bi nepravedno i jednostavno vrlo pogrešno pripisati bilo što negativno Zakladi Prada. Problem je statusa znanja i/ili svjesnosti, odviše snažnog naglaska na kontekstualnoj složenosti koja je, kao što ćemo sada vidjeti, dijalektički polučila upravo suprotno-baš ono čemu se Germano Celant protivi u svojem tekstu gotovo neprestano naglašavajući stvarno: neutralnost bijele kocke. Začudo, to djelo kontekstualizacije, čak i antropološki, kao što to želi Germano Celant, završava proizvodnjom efekta bijele kocke, odnosno nedostatkom konteksta.

Za Celanta, kao i za većinu simplificirajućih ili školskih bavljenja bijelom kockom, ta kocka u svojoj bjelini znači isključivanje svih društveno-povijesnih ili ideoloških okolnosti. Za razliku od toga, on želi rekonstruirati umjetničku produkciju i načine njezina prikazivanja u fašističkoj Italiji. Ipak, zalazeći u cjelokupnost ili cjelovitu sintezu, u antropologiju ili kulturu kao otvorenu, no naposljetku tek nedosljednu cjelinu i u rekonstrukciju životnog prostora, potaknut onim „Prijeđimo na stvarno!", Celant gotovo hoda po žici Einfühlunga, ne toliko u smislu empatije ili suosjećanja, nego općenitije uranjanja, „uživljavanja” i „razumijevanja”. To postaje sasvim doslovno kada se suprotstavlja bijeloj kocki sa svojim izborom arhivskih fotografija, koji je sada moguće oprostoriti i u njega ušetati. No ta je suprotnost opet simplificirana: kako on kaže, fotografije su detaljnije, specifičnije i konkretnije od riječi, koje su odviše apstraktne. One su jednostavno stvarnije, a isto se može reći i za ostalu arhivsku građu. Bijela kocka nije stvarni prostor. Celanta zanima sama srž, složenosti živog ili življenog prostora, a ne aseptični bijeli zid koji je sa sebe otresao sve, uključujući i kontekst, kako bi se utišao za volju umjetničkog djela. Njegova potraga za stvarnim tako se približava suvremenoj ideologiji u pozadini tehnološke hipermodernosti forenzike: riječi nisu dovoljne (pa tako ni umjetnička djela), obmanjuju ili ostaju nejasne u svojoj apstraktnosti pa je stoga objektivna istina na strani empirijske, činjenično pojmljive materijalnosti dokumentarnog konteksta, koju je moguće analizirati. Apstraktnost valja prizemljiti i ponovno je usaditi u život. ${ }^{8}$

Libidinalna ekonomija arhivomanije (ništa novo u svijetu umjetnosti) sada postaje kristalno jasna: suprotstavljanje apstraktne bijele kocke konkretnosti i specifičnosti, pa čak i prizemljenosti arhiva i osobito fotografija predstavlja-psihički i fizički-određeni povratak kući, neku vrstu reteritorijalizacije bijele kocke. Ona (ponovno) proizvodi ili (ponovno) stvara tvrdu stvarnost-prljajući aseptične bijele zidove i fetiš autonomnoga umjetničkog djela kontekstom. Međutim, ono što Celant ne uspijeva artikulirati jest to da je i ta deteritorijalizirana, desupstancijalizirana bijela kocka itekako stvarna, sasvim stvarna apstrakcija, pojmimo li kapitalizam kao sustavnu interakciju deteritorijalizacije ili desupstancijalizacije s jedne strane te reteritorijalizacije ili resupstancijalizacije s druge. Da pribjegnemo određenoj simplifikaciji: bijela kocka već jest politika kao neutralnost, ona jest kontekstualna. Kontekst nije jednostavno i logično oko umjetničkog djela, nego u umjetničkom djelu jednako kao i u samoj boji i obliku bijele kocke. Bijela kocka ne znači nedostatak konteksta. Sam njezin oblik i pojavnost već jesu kontekst. Arhivski je povratak kući, dakle, u libidinalnom smislu umirujuće reteritorijalizirajuće uzemljenje.

Navikli smo na opće mjesto da je kontekst ono što je okruživalo ili okružuje umjetničko djelo: njegove povijesne, društvene ili druge okolnosti. Na taj se način kontekst obično „primjenjuje” na umjetničko djelo izvana. Međutim, čim se posvetimo pitanju umjetnosti kao simptoma, ${ }^{9}$ situacija postaje malo teža. Ukratko i jednostavno rečeno, kontekst bi trebalo izvesti ili razviti počevši od predmeta kao artefakta ili umjetničkog djela, uključujući prostor kao predmet, odnosno od onoga što se proizvodi, čak i ako je neopipljivo, da tako kažemo. Nadalje, to podrazumijeva drugačiji pristup formi i obliku pojavnosti predmeta,

\section{7}

Vidi o tome: Alenka Zupančič, „Kostimografija moči”, 70, koji se ustvari suprotstavlja Žižekovu „pro-Leni” izboru. Sadrži li otvoreno propagandističko djelo Riefenstahlove, poput Trijumfa volje, mogućnost nadilaženja ideološkog konteksta? Ili je to moguće samo represijom kroz potpunu svjesnost?

Tu se možemo ubrzo naći u staroj i lažnoj suprotnosti objektivnog i subjektivnog, naivnog povijesnog/povjesničarskog realizma i diskurzivizma. O tom pitanju vidi poglavlje "The Violence of Interpretation” u: Slavoj Žižek, The Plague of Fantasies. 
political repercussions)? What if our erudite knowledge of the horrors of a certain system can act as an alibi, actually helping us to enjoy its "artworks" without any bad conscience, since we know all too well how things stood? ${ }^{7}$ In this light, though, it would be unjust and simply very wrong to impute anything negative to the Fondazione Prada. The problem is the status of knowledge and/or awareness, the all-too-strong emphasis on contextual complexity that brought about, as we shall now see, and dialectically, the exact opposite-exactly what Germano Celant goes against in his text by almost constantly underlining the real: the neutrality of the white cube. Strangely, the work of contextualizing, even anthropologically as Germano Celant would have it, ends up producing the effect of the white cube, namely, the absence of context.

For Celant, like for most commonplace or textbook takes on the white cube, the cube means, in its whiteness, the exclusion of all socio-historical or ideological circumstances. In contrast, he is interested in the reconstruction of the artistic production and its modes of display in fascist Italy. Yet going into totality or total synthesis, into anthropology or culture as an open-ended, but ultimately just an inconsistent whole, and going into the reconstruction of the life-space, propelled as he is by the impetus of "Let's get real!," Celant almost walks the tightrope of Einfihlung, not so much in terms of empathy or sympathy but more generally of immersion, "feeling into" and "understanding." This becomes quite literal when he opposes the white cube with his choice of archival photographs, which one can now spatialize and walk into. The opposition is again too commonsensical: as he states, photographs are more detailed, more specific and more concrete than too-abstract words. They are simply more real, and the same could be said of other archival materials. The white cube is not real space. Celant is interested in the nitty-gritty, the complexities of the living or lived space, not the aseptic white wall that shed everything, including context, in order to quiet itself for the sake of the artwork. His quest for the real thus comes close to the contemporary ideology underlying the technological hypermodernity of forensics: words are not enough (and for that matter artworks too), they deceive or remain unclear in their abstractness, and so the objective truth is on the side of the empirical, the factually graspable, analyzable materiality of the documentary context. One needs to ground the abstractness, re-insert it back into life. ${ }^{8}$

The libidinal economy of the archives frenzy (nothing new in the art world) now becomes glaring: opposing the abstract white cube with the concreteness and specificity, even the earthiness of archives and especially photographs enacts psychically and physically - a certain homecoming, a sort of reterritorialization of the white cube. It (re-) produces or (re-) creates the hard reality-it soils the aseptic white walls and the fetish of the autonomous artwork with context. However, what Celant fails to articulate is that the deterritorialized, desubstantialized white cube is also very much real, a very real abstraction, if we think capitalism as a systemic interplay of both deterritorialization or desubstantialization and reterritorialization or resubstantialization. To put it somewhat simplistically: the white cube already is politics as neutrality, it is contextual. The context is not simply and commonsensically around an artwork, it is in the artwork as much as it is in the very color and form of the white cube. The white cube does not mean the absence of context. Its very form and appearance already are the context. The archival homecoming is thus libidinally an appeasing reterritorializing grounding.

We are used to the commonplace that context is taken to be what surrounded or surrounds the artwork, be it its historical, societal or other circumstances. In this way, context is usually "applied" to the artwork from the outside. However, the moment we turn to the question of art as a symptom ${ }^{9}$ the situation becomes a bit more difficult. In short, and simply put, context should be derived or developed starting from the object as artefact or artwork, including space as an object, i. e., from what is produced, even if intangible, so to speak. Furthermore, this entails

\section{7}

See this point in Alenka Zupančič's text "Kostumografija moči," 70. It in effect goes against Žižek's pro-Leni choice. Does Riefenstahl's openly propagandistic work, like the Triumph des Willens, contain the possibility of going beyond its ideological context? Or is that only by repression via full awareness?

8

Here, we can quickly find ourselves in the old and false opposition between the objective and subjective, between naive historical / historiographical realism and discursivism. For this question see the chapter "The Violence of Interpretation" in Slavoj Žižek's The Plague of Fantasies. See: Wajcman, Collection. 
i to ne samo u smislu formalne analize. Kontekst bi stoga bio ona točka u formi gdje u prvi plan stupa druga „linija priče”, odnosno nešto što se „artikulira” unatoč službenoj ideologiji ili društveno-povijesnim okolnostima, a što tako rasvjetljuje što službena linija ne može a da i nehotice ne pokaže u svemu što dotakne. Njezina unutarnja zapreka ili točka nedosljednosti „,artikulira” se nesvjesno, iza leđa samog konteksta, uključujući i umjetnika i umjetničko djelo. To je kao da umjetnost, koliko god propagandistička bila, ima pomalo jezivu sposobnost da pokaže intimnu ili sjenovitu stranu određenog sustava, njegovu točku sukoba, nedosljednosti ili antagonizma, ono s čime se taj sustav bori i što ne može priznati. Ovdje možemo definitivno govoriti o povijesti i nesvjesnome. Umjetnost je također mjesto materijalne iskrenosti ideoloških zdanja, od njihovih fantazmatskih potpornjaka naviše. ${ }^{10}$

Ta neobična i dijalektički neutralizirajuća uloga kontekstualizirajućih fotografija i arhiva prelijeva se u Celantovu koncepciju prostora, što je, iako Celant ide protiv modernizma bijele kocke, u potpunosti vezano uz gesamt ili cjelokupni doživljajdoživljaj koji je u velikoj mjeri dio romantičarskog nasljeđa Gesamtkunstwerka, što se lako može primijetiti u načinu na koji su modernistički i avangardni umjetnici tretirali prostor barem od secesije nadalje. Kao totalni i totalizirajući sintetski doživljaj. ${ }^{11}$ Walk-in fotografije, čak i ako je to ušetavanje mentalno, jesu kontekst (odnosno njegova realizacija), više ili manje na rubu uronjavanja u izvorni kontekst (kontekste) tipa Einfühlunga. Je li u konačnici riječ uvijek o tome da je kontekst (konteksti) sposoban pridati značenje umjetničkom djelu? Za bolje ili novo razumijevanje? Je li to potraga za izvornim značenjima iz razdoblja od 1918. do 1943.? Je li to razdoblje bilo svjesno tih značenja? Razmatrajući pojam „prostora” također kao pozornice za predmet, Celant lijepo pokazuje kako je prostor u pitanju od 19. stoljeća nadalje naposljetku simbolični prostor interakcije označitelja ili pridavanja značenja umjetničkom djelu, koje se odjednom čini poput prazne posude, daleko od autonomnoga, neke vrste posude-prostitutke koja čeka da je ispune različitim prostorima, odnosno kontekstima/publikama. To je strogo unutar granica fenomenološke ili čak avangardne estetike, u kojoj gledatelj ispunjava prazninu predmeta-jednostavno ga uokvirujući ili, u kontekstu izložbe, stavljajući ga u okvir „izvornog” konteksta koji je doslovce oprostorena fotografija.

Nadalje, modernističko nasljeđe može se zamijetiti i u načinu na koji je Celant pretvorio prostore u prostore-predmete. Dakako, svjesno ih je oponašao, ponovno stvorio. I tu bismo mogli reći kako je upravo ta čudnovata, prilično pretjerano osmišljena i brižljiva neutralnost ono što ustvari omogućuje distanciranost od onoga što bi mogla postati kostimirana drama, pod uvjetom, dakako, da imamo i kritičko znanje ili sud o fašizmu. Ipak, i tu postoji previše riskantne ambivalentnosti, ne samo u smislu mogućeg skrivanja iza akademske neutralnosti, koja se temelji na vrlo naivnoj i toliko puta već prevladanoj ideji objektivnosti. Suprotno, naime, moguću fascinaciju bogatstvom kulture pod fašizmom i odviše je lako postići. Otkuda taj nedostatak jasne prosudbe? Drugim riječima, jednostavna je činjenica da je ono što se događalo u većini izložbenih prostora za vrijeme fašizma u smislu kulturne politike bilo naličje nečega nepodnošljivo zlokobnijeg izvan tih prostora-bi li se netko usudio rekonstruirati imerzivan doživljaj tog drugoga? Strašna pomisao. Ali nije li Celant bio zainteresiran za cjelokupnost stvari? Ili je ta druga strana danas i odviše očigledna za izložbu?

Čini se kao da su svi prošli i suvremeni povijesni akteri, posebno u ovom delikatnom slučaju koji se tiče jednog brutalnog režima, težili cjelovitom, gesamt doživljaju. Putanja je stoga u osnovi sljedeća: ono čime se ovdje bavimo permutacije su logike u pozadini establišmenta bijele kocke, koja je sama po sebi već sasvim kontekstualna ili partikularna utoliko što je lišena konteksta i stoga naizgled univerzalna. (Lažna) slika je da bijela kocka nije jedna od mnogih partikularnosti, nego prazan globalni kontejner koji se može ispuniti bilo čime što ga neće naposljetku poremetiti. Kritički pristup bio bi pokazati koliko partikularna, povijesna,

\section{0}

Vidi Žižekove informativne primjere tog pristupa likovnoj umjetnosti kao simptomu u: Žižek, The Plague of Fantasies, 3-4.

Vidi, na primjer: Lista, L'CEuvre d'art totale à la naissance des avant-gardes. 
a different approach to form and mode of appearance of the object, not just in terms of a formal analysis. Context would thus be the point in the form, where another "storyline" comes to the foreground, i. e., something that is "articulated" against the grain of an official ideology or socio-historical circumstances, thereby shedding light on what the official line cannot help but inadvertently show in everything it touches. Its inner impediment or point of inconsistency is "articulated" unwittingly, à l'insu of the context itself, including the artist and the artwork. It is as if art, as propagandist as it may be, has the uncanny ability to show the intimate or shadow side of a certain system, its point of conflict, inconsistency or antagonism, what the system is grappling with and cannot acknowledge. Here, we could definitely speak of history and the unconscious. Art too is the place of the material honesty of ideological edifices, from their fantasmatic support onward. ${ }^{10}$

The strangely and dialectically neutralizing role of contextualizing photographs and archives spills into Celant's conception of space, which is, even if Celant goes against the modernism of the white cube, thoroughly attached to a gesamt or total experience-an experience very much a part of the romanticist Gesamtkunstwerk legacy that one can easily notice in the way modernist and avant-garde artists treated space from at least the Secession onward. As a total and totalizing, synthetic experience. ${ }^{11}$ The walk-in photographs, even if the walking-in is mental, are (the realization of) the context, more or less on the brink of the Einfuihlung immersion into the original context(s). Is this in the last instance all about the context(s) having the ability to confer meaning upon the artwork? For a better or new understanding? Is it a quest for the original meanings from the I9I8-I943 period? Was that period aware of those meanings? When considering the term "space," also as a stage for the object, Celant nicely shows how the space in question from the I th century onward is ultimately the symbolic space of the interplay of signifiers or of bestowing meaning upon the artwork, which suddenly seems like an empty, far from autonomous, some sort of a prostitute vessel waiting to be filled by different spaces, i. e., contexts/publics. This is strictly within the limits of the phenomenological or even avant-garde aesthetics where the spectator fills in the emptiness of the object-simply frames it, or in the context of the exhibition puts it in the frame of the "original" context that is quite literally a spatialized photograph.

Furthermore, the modernist legacy can also be traced in the way Celant transformed spaces into space-objects. Of course, he consciously mimicked them, recreated them. Again, we could claim here that it is that strange, pretty much overly-designed and studious neutrality that can actually enable the distance toward what could become a costume drama, provided, of course, that we also have a critical knowledge or judgement of Fascism. Still, there is too much of a tightrope ambivalence here, not only in terms of a possible hiding behind academic neutrality, based on a very naïve and so many times surpassed idea of objectivity. The opposite, namely, a possible fascination with the cultural wealth under Fascism is too easily attracted. Why this lack of a clear judgement? In other words, the simple fact is that what was going on in most of the exhibition spaces during Fascism in terms of cultural policies was the other side of something unbearably more sinister outside these spaces - would one dare to reconstruct an immersive experience of that? A dreadful thought. But was Celant not interested exactly in the totality of things? Or is that other side today all too evident for an exhibition?

It seems as if all the past and contemporary historical players, especially in this delicate case as far as a brutal regime is concerned, were aiming for a total, gesamt experience. The trajectory is therefore basically as follows: what we are dealing with here are the permutations of the logic behind the establishement of the white cube, in itself already thoroughly contextual or particular inasmuch as it is devoid of context and thus seemingly universal. The (false) image is that the white cube
10

See Žižek's informative examples of this approach to the visual arts as a symptom in The Plague of Fantasies, 3-4.

11

See, for instance: Lista, L'Euvre d'art totale à la naissance des avant-gardes. 
politička i ideološka, odnosno kapitalistička, bijela kocka ustvari jest-pokazati ono što ona potiskuje u skoku iz neutralnosti u ono što ju je diskurzivno i povijesno omogućilo, u procese u njezinoj pozadini, koji onda postaju vidljivi u samoj pojavi njihove suprotnosti: neutralne bjeline, koja skriva da nije ništa drugo do „kostimografija moći”. Ipak, bio bi korak predaleko primijeniti ovo na gotovo sve kao krajnji obzor, uključujući avangardne umjetnike. Prva je permutacija u logici bijele kocke Studio per la sala P de la Mostra della Rivoluzione Fascista (1930.1932.) Marija Sironija, koja prlja „neutralnu” bijelu kocku „kontekstom”-fašizmom. Preuzimanje ili očigledno kostimiranje praznog prostora i njegovih zidova nije potisak protiv bijele kocke, nego potisak prema onome što će postati nova neutralnost. Nova pozadina samog života. Ovo je definitivno najsjajniji, ako ne i potpuno artikulirani aspekt Celantova teksta: borba je bila i ostaje borba za pozadinu, borba onih koji će preuzeti bjelinu i time kontrolirati pozadinu, između ostaloga kroz umjetnost $i$ kulturu. Fašizam tako ponavlja kapitalističku deteritorijalizaciju ili desupstancijalizaciju putem njezine reteritorijalizacije i supstancijalizacije vlastitom partikularnošću kao novom neutralnošću u nastanku, koja će biti sam život. Drugim riječima, fašizam stvara vlastiti povratak kući time što kapitalizmu daje ljudsko lice, lice neantagonističkog, predmodernog „društva” u hipermodernosti kapitalizma. Nije ni čudo da taj doživljaj mora biti gesamt. To mora biti tlo po kojem će svi hodati, no njegova nametnuta novost mora biti organska i sveobuhvatna. Sasvim doslovno, od umjetnosti do ukrašavanja doma i svih drugih aspekata života. Simptomatična točka, toliko usko povezana s ovim gesamt doživljajem koji nastoje uhvatiti walk-in fotografije, stoga je ustvari dizajn: umjetnost se sve više spaja s dizajnom za život i dizajnom života.

Primjer Sironija stoga je samo vizualno različit od bijele kocke-vizualni je rezultat različit, no logika i cilj su isti. Cilj je neutralnost. Treća permutacija bila bi zatim Celantova: ponovno uokvirivanje obaju okvira, odnosno ponovljena gesta razbijanja bjeline, no s namjerom potpunog razotkrivanja onoga što i bijela kocka i Sironijev primjer izostavljaju ili potiskuju. Čak i ako je Celantov napad na bijelu kocku ispravan, iako previše standardan, pa čak i ako učenost nije dovoljna, postoji više istine u toj „neutralnosti” (ili dizajnu uvijek lažne neutralnosti) nego što se čini. Postoji istina u lažnosti pojavnosti, u postajanju-neutralnim. No nesvjesno. I opet: u čemu je onda problem? Kao što sada možemo lako vidjeti, problem nije jednostavno u tome kako razbiti bijelu neutralnost (u kritičkoj analizi, na primjer), nego u činjenici da njezina čarolija može funkcionirati i ustrajati kao neupitan i nepokolebljiv identitet, kao pozadina koja bi bila sam život, unatoč kritičkoj analizi, našem znanju ili svjesnosti. Tu dolazimo do najmračnijeg aspekta ovog povijesno-umjetničkog manevra: nije li riječ o tome da je tim u pozadini kataloga i izložbe bio nesvjestan ili čak ublažavao fašizam, kako bi neki hiperkritički smatrali-bili su i više nego svjesni kako je fašizam „,isprao mozak svojega stanovništva, odveo ga u rat, nametnuo kolonijalnu dominaciju Etiopiji, Libiji i Albaniji, donio rasne zakone, ubijao članove parlamenta, ušutkavao disidente i osudio na tisuće osoba na deportaciju i smrt”. ${ }^{12}$ Fetiš je to što „oni znaju” i što „mi znamo”. Svi mi to dobro znamo-i predobro. To je opće znanje i upravo u tome je problem: sve je to sasvim uobičajeno. Barem u učenim krugovima. Učenost je ovdje fetiš-to je stvaranje tampon-zone. Znanje ne sprječava fetišizaciju. Upravo obrnuto, može je hraniti. To je razlog zbog kojega ta stvar i dalje ustraje unatoč znanju, pa čak i zbog našeg znanja. I zato Celantova knjiga, standardni ili danas jednostavno normativni napad na bijelu kocku s fotografijama i arhivima, ali još više s podacima, nije dovoljna. Otkrivajući prošli kontekst, on ustvari otkriva današnji: suvremena ideologija uspješno prikriva mehanizme represije, čineći ih nedostupnima pod gomilom znanja o „potisnutom sadržaju”. ${ }^{13}$ Upravo zbog toga kontekstualizacija i sama može odvesti u „neutralnost”. 13

Iz ogleda Barbare Casavecchia (vidi bilj. 5).

Zupančič, „Kostumografija moči”, 71. . 
is not a particularity among many others but an empty global container that can be filled with anything that will ultimately not disrupt it. The critical approach would be to show how particular and historical and political and ideological, i. e., capitalist, the white cube actually is - to show what it represses in the jump from its neutrality to what discursively and historically made it possible, to the processes behind it, which then become visible in the very appearance of their opposite: the neutral whiteness, which hides that it is nothing but the "costimography of power." Still, it would be a step too far to apply this to just about anything as the ultimate horizon, the avant-garde artists included. The first permutation in the white cube's logic would be Mario Sironi's Studio per la sala P della Mostra della Rivoluzione Fascista (I930-I932), soiling the "neutral” white cube with "context"Fascism. The overtaking or obvious costuming of the empty space and its walls is not a push against the white cube, but the push for what is going to be the new neutrality. The new background of life itself. This is definitely the most brilliant, if not fully articulated aspect of Celant's text: the fight is and was the fight for the background, the fight of who will take over the whiteness and thus control the background, through art and culture no less. Fascism thus repeats the capitalist deterritorialization or desubstantialization by reterritorializing and substantializing it with its own particularity as the new, emerging neutrality that will be life itself. In other terms, Fascism creates its own homecoming in giving capitalism a human face, that of a non-antagonistic, pre-modern "society" in the hypermodernity of capitalism. No wonder the experience must be gesamt. It has to be the ground everybody will walk on, yet its imposed novelty should be organic and all-encompassing. Quite literally, from art to home decor to all aspects of life. The symptomatic point, so closely linked to this gesamt experience chased by the walk-in photographs, is therefore actually design: art merging more and more with a design for life and a design of life.

The Sironi example is thus only visually different from the white cube - the visual result is different, but the logic and goal are the same. The goal being neutrality. The third permutation would then be Celant's: a reframing of both frames, i. e., repeating the gesture of breaking the whiteness, yet going for full disclosure of what both the white cube and the Sironi example leave out or repress. Even if Celant's attack on the white cube is right, even if all too standard, and even if erudition is not enough, there is more truth in this (design of an always fake) "neutrality" than may appear. There is truth in the falsity of appearance, in the becoming-neutral. Unwittingly so. Again: What is the problem then? As we can now easily see, the problem is not simply how to dispel the white neutrality (in a critical analysis, for example), but the fact that its spell can work and stick as a non-questionable, unshakeable identity, as the background that would be life itself, in spite of a critical analysis, our knowledge or awareness. Here, we come to the darkest aspect of this art-historical tour de force: it is not that the team behind the catalogue and exhibition was unaware or even downplaying Fascism as some would hypercritically have it - they were more than aware of how Fascism "brainwashed its population, brought it to war, imposed colonial domination upon Ethiopia, Libya and Albania, promulgated racial laws, killed members of parliament, silenced dissidents and condemned to deportation and death thousands of people." 12 The fetish is that "they know" and that "we know." We all know very well-too well. It is common knowledge and that is exactly the problem: that it is all too common. At least in the erudite circles. Erudition is the fetish here-it is the creation of a buffer zone. Knowledge does not impede fetishization. Quite the opposite, it can nourish it. This is why the thing continues to stick despite and even because of our knowledge. And this is why Celant's textbook, standard or now simply normative attack on the white cube with photographs and archives, yet even more data, is not enough. In disclosing the past context it actually discloses the present one: the contemporary ideology "successfully covers up the mechanisms of repression,

making them inaccessible under a pile of knowledge of 'repressed contents,", 13 Zupančič, "Kostumografija moči," 7I. This is why contextualization can itself lead into "neutrality."
12

From Barbara Casavecchia's review (see note 5). - 


\section{POPIS LITERATURE / BIBLIOGRAPHY}

Casavecchia, Barbara. „Post Zang Tumb Tuuum. Art Life Politics: Italia 1918-1943 at Fondazione Prada, Milan",Art Review. https://artreview.com/reviews/ar_april_2018_review_post_zang_ prada/ (pristupljeno 5. studenoga 2018./last accessed on November 5, 2018).

Celant, Germano, Costa, Chiara, ur./ed. Post Zang Tumb Tuuum. Art, Life, Politics: Italia 1918-1943. Milano-Venezia: Fondazione Prada, 2018.

Lista, Marcella. L'CEuvre d'art totale à la naissance des avant-gardes. Paris: Comité des travaux historiques et scientifiques, 2006.

Wajcman, Gérard. Collection. Caen: Nous, 2003.

Zupančič, Alenka. „Kostumografija moči” [The costimography of power]. Problemi: revija za kulturo in družbena vprašanja 5-6 (2014.): 41-72.

Žižek, Slavoj. The Plague of Fantasies. London-New York: Verso, 1997.

Žižek, Slavoj. „Learning to Love Leni Riefenstahl”, Septembre 10, 2003. http://www.lacan.com/ zizekleni.htm (pristupljeno 5. studenoga 2018./last accessed on November 5, 2018). 


\section{ŽIVOT UMJETNOSTI}

